\title{
OPTIMALISASI PEMBELAJARAN PENDIDIKAN AGAMA ISLAM (PAI) MELALUI GOOGLE CLASSSROOM
}

\author{
Eko Purnomo Susanto (1) \& Rahmatullah (2) \\ (1) Mahasiswa PAI STAI Ma'had Aly Al Hikam Malang \\ (2) Dosen STAI Ma'had Aly Al Hikam Malang \\ Email : ekopurnomosusanto@gmail.com \\ Email: rahmat281086@gmail.com
}

\begin{abstract}
The development in the information and communication technology is a blessing and a gift from Allah which is given to humanity. Internet and virtual media facilities make it easy for humans to access information and socialize without being blocked by time and space. This development has a positive impact on the development of learning in this digital era. The habituation and optimization of Islamic religious education learning through Google Classroom is one way to foster the ability of learners of this century. This research involved sixth grade students at MI Islamiyah City of Malang. The results of this study indicate that the optimization of learning through Google Classroom has an impact in preparing the learning process of Islamic religious education, so that it can be a positive provision in transfer of knowledge.
\end{abstract}

\begin{abstract}
Abstrak
Perkembangan di bidang teknologi informasi dan komunikasi merupakan nikmat dan karunia Allah yang dikaruniakan kepada umat manusia. Fasislitas internet dan media virtual, memudahkan manusia dalam mengakses informasi dan bersosialisasi tanpa disekat oleh ruang dan waktu. Perkembangan ini berdampak positif bagi perkembangan pembelajaran di era digital ini. Pembiasaaan dan optimalisasi pembelajaran pendidikan agama Islam melalui Google Classroom merupakan salah satu cara untuk menumbuh kembangkan kemampuan peserta didik abad ini. Penelitian ini melibatkan siswa-siswi kelas VI di MI Islamyyah Kota Malang. Hasil penelitian ini menunjukkan bahwa optimalisasi pembelajaran melaui Google Classroom memiliki dampak dalam mempersiapkan proses pembelajaran pendidikan agama Islam, sehingga bisa menjadi bekal yang positif dalam memperoleh ilmu pengetahuan (transfer of knowledge).
\end{abstract}

Kata kunci: Optimalisasi Pembelajaran, PAI, Google Classroom 
JURNAL PIWULANG, Vol. 2 No. 2 Maret 2020, 129-143

P-ISSN : 2622-5638. E-ISSN : 2622-5654

Homepage: http://e-journal.staima-alhikam.ac.id/index.php/piwulang

\section{A. Pendahuluan}

Pembelajaran pendidikan agama Islam di lembaga pendidikan sudah sering kita dengar dan tak asing lagi ditelinga. Metode tersebut diajarkan disekolah-sekolah baik disekolah umum, maupun sekolah berbasis agama (madrasah). Proses transfer ilmu dari seorang guru kepada para siswanya membutuhkan suatu metode, strategi maupun cara tertentu untuk memindah ilmu pengetahuan kepada peserta didik. Bukubuku yang diajarkan selama ini kepada siswa-siswi kelas 6 MI Islamiyah sebagai tuntutan kurikulum yang dibebankan oleh Pemerintah kepada lembaga pendidikan. Penyampaian materi, pemberian tugas-tugas biasanya melalui media tertentu. Untuk mempermudah proses belajar mengajar menggunakan teknologi.

Penggunaan teknologi dalam proses belajar mengajar memberikan kesempatan dan peluang bagi tenaga pendidik dalam hal ini guru agar dapat meningkatkan dan mengembangkan kompetensinya terutama profesionalitas mereka. Penggunaan teknologi dalam masalah pembelajaran di kelas yang disebabkan oleh kurang optimalnya peran guru dalam memanfatkan teknologi yang berkembang dalam memajukan dunia pendidikan. Masih banyak lembaga pendidikan, kususnya ditingkat bawah belum bisa sepenuhnya mengikuti perkembangan teknologi yang ada. Untuk mengatasi masalah tersebut adalah dengan kemampuan teknologi. Salah satunya adalah memanfaatkan aplikasi tertentu yang bisa dimanfaatkan di lembaga pendidikan utamanya seorang guru dalam kegiatan pembelajaran agama dengan memanfaatkan kemampuan aplikasi Google Classroom.

Penelitian ini merupakan penelitian kualitatif dalam bentuk penelitian lapangan (deskriptif). Pembelajaran PAI , selain disampaikan dengan metode ceramah (Teacher Center) dengan menggunakan media pembelajaran seperti proyektor, papan tulis dan lain-lain, juga dilengkapi dengan pemanfaatan media google classroom oleh kelas 6 di lembaga sekolah MI Islamiyah meskipun belum diterapkan oleh semua guru pengampu mata pelajara di sekolah tersebut. Pembelajaran PAI dilakukan sebanyak 24 jam pelajaran selama satu minggu yang terbagi dalam beberapa mata pelajaran. Jadi, dalam sehari siswa-siswi kelas enam diwajibkan mengikuti pelajaran agama selama 4 jam pelajaran $(4 \times 35$ menit). Dengan metode tersebut Pembelajaran dikelas bisa tersampaikan secara maksimal sesuai dengan kurikulum yang diterapkan di lembaga. 
JURNAL PIWULANG, Vol. 2 No. 2 Maret 2020, 129-143

P-ISSN : 2622-5638. E-ISSN : 2622-5654

Homepage: http://e-journal.staima-alhikam.ac.id/index.php/piwulang

Berdasarkan penelitian literatur, penulis akan lebih spesifik membahas tentang gambaran tentang pembelajaran menggunakan aplikasi google classroom di kelas 6 Lembaga MI Islamiyah, sebagai salah satu metode pembelajaran yang lebih baik.

\section{B. PEMBAHASAN}

\section{1) Hakikat Metode Pembelajaran PAI Melalui Google Classroom}

Google Classroom sebenarnya adalah satu alat yang dirancang untuk mempermudah interaksi seorang pendidik dengan peserta didik dalam dunia internet. Aplikasi ini akan memberikan kemudahan kepada para pendidik (guru) untuk mengeksplorasi gagasan keilmuan yang dimiliki yang selanjutnya diberikan kepada peserta didik. Guru memiliki keleluasaan waktu atau kesempatan yang lebih untuk membagikan ilmu pengetahuan dan memberikan tugas-tugas yang dikerjakan diluar sekolah atau biasa dinamakan dengan tugas mandiri (take home) kepada para siswanya. Selain itu, guru juga kesempata kepda para siswa yang mereka didik agar terbiasa dengan tekonologi ( IT ). ${ }^{1}$ Namun demikian, terdapat syarat mutlak bagi pengguna teknologi ini adalah tersedianya akses internet yang mumpuni agar pengoperasian aplikasi ini bisa berjalan sesuai rencana tanpa terkendala apapun. Rancangan kelas yang menggunakan aplikasi google classroom sesungguhnya ramah lingkungan. Hal ini dikarenakan salah satu kebijakan lembaga untuk mengurangi ketergantungan kertas dalam mengumpulkan tugas, mengikuti penilaian harian (PH), try out, UTS, ujian semester dan lain-lain. Lebih dari itu juga mengurangi beban sekolah dalam pengadaan kertas untuk tugas para siswa dan lebih praktis tentunya.

Aplikasi ini merupakan sebuah terobosan baru yang diciptakan oleh google yang mana denghan kecangggihan yang dimilikinya memungkinkan terciptanya ruang kelas tanpa proses tatap muka. Para siswa yang tergabung dalam aplikasi tersebut, bisa mengecek setiap tugas yang diberikan oleh Bapak/ibu guru pada laman tugas yang tersedia di aplikasi tersebut dengan cara mudah dengan sekali klik saja. Sehingga, mereka segera merespon tugas-tugas yang dikirim lewat aplikasi tersebut. Seorang guru sebagai pemeran utama dalam kelas ini bisa melihat dengan cepat siapa saja dari siswanya yang telah menyelesaikan tugas, sehingga media ini bisa dijadikan control

\footnotetext{
1 Abd Rozak, Azkia Muharrom Albantaini, Desain Perkuliahan Bahasa Arab Melalui Google Classrom, Vol 5 No.1, Juni 2018, diakses tanggal 17 Oktober 2019
} 
JURNAL PIWULANG, Vol. 2 No. 2 Maret 2020, 129-143

P-ISSN : 2622-5638. E-ISSN : 2622-5654

Homepage: http://e-journal.staima-alhikam.ac.id/index.php/piwulang

kegiatan siswa diluar sekolah. Perkembangan teknologi informasi yang semakin pesat khususnya dengan media google classroom ini bisa mengembangkan layanan informasi yang lebih baik di lembaga pendidikan (sekolah).

Di Madrasah Ibtidaiyah Islamiyah misalnya, pemanfaatan Teknologi Informasi dan Komunikasi diwujudkan untuk pengembangan madrasah sebagai sarana mempermudah proses pembelajaran PAI dengan memanfaatkan google classroom, sehingga siswa bisa berlatih dengan cepat tentang cara mengaplikasikan media tersebut. Penggunaan google classroom dilingkungan sekolah bertujuan untuk mempermudah akses pembelajaran khususnya pelajaran agama oleh guru pengampu bisa dengan mudah dan cepat tersampaikan. Selama ini pembelajaran di kelas lebih banyak memakai metode teacher center, maka perlu desain pembelajaran yang lebih kompetitif dengan perkembangan jaman. Salah satunya adalah dengan menggunakan cara atau metode yang sesuai dengan yang dibutuhkan dengan kebutuhan saat ini.

Google classroom sebagai salah satu media pembelajaran PAI yang perlu dicoba dan dimaksimalkan di Madrasah. Ini dilakukan untuk meningkatkan kemampuan peserta didik agar terbiasa dengan pembelajaran dengan media yang lebih canggih dari biasanya. Aplikasi ini digunakan sebagai alternatif mata pelajaran agama yang diajarakan oleh guru PAI dalam memberikan tugas-tugas yang diberikan kepada anak didik yang bisa dibagi melaui aplikasi ini.

Dalam praktik penggunaannya, google classroom sangat mudah untuk digunakan kedalam kegiatan pembelajaran. Kita bisa mendapatkan aplikasi ini secara mudah dengan cara mengunduhnya secara cuma-cuma diperangkat smartphone berbasis android. Dikalangan pelajar tingkat dasarpun bisa dengan mudah mengakses aplikasi tersebut di handphone mereka. Namun untuk para pemula perlu arahan dari orang lain yang lebih paham untuk menggunakan aplikasi ini yang sebaiknya mendengar penjelasan dalam menggunakan aplikasi tersebut agar lebih paham serta menghindari kebingungan bagi siswa dalam menggunakannya. Selain itu, pengguna juga mengikuti perkembangan dengan terus memutakhirkan pengetahuan fitur google classroom itu dikarenakan aplikasi ini terus ter-upgrade sesuai dengan kadaluarsa dan tentunya kita tidak boleh ketinggalan dengan informasi ini. 
JURNAL PIWULANG, Vol. 2 No. 2 Maret 2020, 129-143

P-ISSN : 2622-5638. E-ISSN : 2622-5654

Homepage: http://e-journal.staima-alhikam.ac.id/index.php/piwulang

Mengaplikasikan Google Classroom tentunya bukan suatu hal yang mudah bagi seorang guru yang tidak memiliki kemampuan dalam mengoperasikan fitur tersebut. Butuh kemampuan khusus dalam bidang teknologi informasi dan komunikasi (TIK). Namun bagi orang yang sudah memahami ilmu tersebut, tentu dengan mudah dalam mengaplikasikan Google Classroom.

\section{2) Langkah-Langkah Pengoperasian Google Classroom pada Pembelajaran PAI}

Belajar pada hakikatnya adalah proses, perubahan dari awalnya belum bisa menjadi bisa, belum tahu menjadi tahu, belum paham menjadi paham. Untuk mendapatkan hasil yang direncanakan sesuai tujuan pembelajaran di Madrasah, tentu seorang guru harus memiliki strategi dan metode pembelajaran untuk mencapai tujuan yang diinginkan oleh lembaga tersebut, sebagaimana Visi yang diinginkan oleh lembaga Madrasah Ibtidaiyah Islamiyah adalah "Meluluskan siswa yang berakhlakul karimah dan Berprestasi Akademik yang Optimal"

Untuk mencapai Visi tersebut, tentunya dibutuhkan suatu cara / strategi pembelajaran agar pelaksanaan proses belajar mengajar di dalam kelas bisa berjalan dengan baik. Faktor guru dalam menggunakan metode dan strategi haruslah tepat sesuai situasi dan kondisi dilapangan. Perlu kerja keras dari semua pihak yang terkait dengan pelaksanaaan belajar mengajar. Salah satu upaya yang dilakukan oleh guru pengampu mata pelajaran agama dalam menyampaikan tema yang akan disampaikan menggunakan aplikasi google classroom.

Untuk mempermudah pengoperasiannya, dapat dipelajari dengan memperhatikan langkah-langkah yang akan kami jelaskan berikut : ${ }^{2}$

a) Buka laman google lewat laman Mozilla Firefox atau Google Chrome, lalu buka tautan Google Classroom.

\footnotetext{
${ }^{2}$ Abd Rozak, Azkia Muharrom Albantaini, Desain Perkuliahan Bahasa Arab Melalui Google Classrom, Vol 5 No.1, Juni 2018, diakses tanggal 17 oktober 2019
} 
JURNAL PIWULANG, Vol. 2 No. 2 Maret 2020, 129-143

P-ISSN : 2622-5638. E-ISSN : 2622-5654

Homepage: http://e-journal.staima-alhikam.ac.id/index.php/piwulang

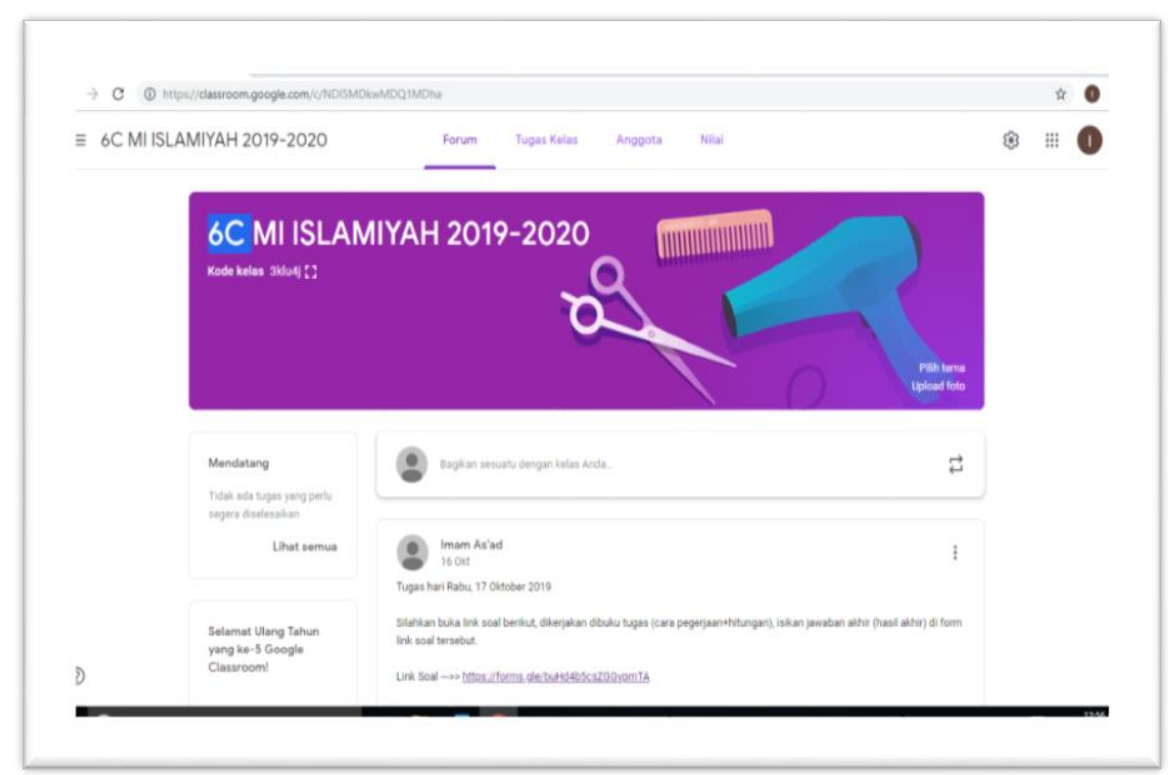

b) Pastikan guru dan siswa telah memiliki akun Google Apps for Education.

Guru dan siswa yang akan tergabung dengan kelas tersebut haruslah punya akun tersebut, dengan memiliki akun itu guru dan siswa bisa mengaplikasikan google classroom. Selanjutnya kunjungi situs classroom.google.com dan sign in. Guru selaku pengatur kelas itu bisa meng-klik tulisan guru untuk membuat kelas. Pun sebaliknya, jika siswa, maka klik tulisan siswa agar bisa tergabung dengan kelas yang dibuat guru dengan menggunakan kode yang telah didapatkan.

c) Guru menambahkan siswa secara langsung atau berbagi kode

Langkah ini dilakukan didalam kelas dengan memberitahukan kepada siswa agar bisa bergabung dengan kelas yang dibuat oleh guru. Dia memberitahukan kepada siswa bahwa akan menerapkan google classroom pada mata pelajaran yang diampu. Guru memerintahkan kepada para siswa untuk mengaktifkan email guru sebagai tutor didalam kelas.

d) Guru memberikan tugas mandiri

Tugas ini diberikan oleh guru pengampu sebagai tutor untuk melemparkannya secara mandiri untuk dikerjakan dirumah masing-masing atau waktu belajar kelompok. Tugas-tugas yang dikirim oleh guru melalui google classroom, secara otomatis akan disimpan ke dalam folder google drive.

e) Guru melemparkan informasi mengenai diskusi 
JURNAL PIWULANG, Vol. 2 No. 2 Maret 2020, 129-143

P-ISSN : 2622-5638. E-ISSN : 2622-5654

Homepage: http://e-journal.staima-alhikam.ac.id/index.php/piwulang

Selain memberikan tugas-tugas yang bersifat individu ataupun kelompok. Aplikasi ini bisa memberikan informasi sesuai tema pelajaran PAI yang disampaikan kepada para siswa sesuai dengan Rencana Pelaksanaan Pembelajaran (RPP).

f) Bisa digunakan sebagai tempat diskusi

Guru dan siswa yang tergabung dengan kelas ini bisa saling bertanya antara satu dengan yang lain tentang tema yang sedang dibahas di dalam google classroom ini jika terdapat materi yang kurang dipahami. Siswa bisa mengetahui setiap tugas yang diberikan oleh guru pengampu dan bisa mengetahui batas waktu pengumpulan tugas, serta mengerjakan tugas tersebut dengan sesegera mungkin. Guru pun bisa melihat dengan cepat siapa saja dari siswanya yang telah menyelasikan tugas yang berikan guru pengampu pelajaran agama di lembaga tersebut. Dengan mengetahui tugas yang telah dikerjakan siswa, guru bisa memberikan masukan kepada mereka mengenai tugas yang telah dikerjakan sat itu juga melalui aplikasi tersebut.

Salah satu contoh seorang Guru ingin mejelaskan tema Lingkungan kepada para siswanya dan salah satu upaya mendapatkan media ajar adalah dengan searching di internet terlebih dahulu sebelum melemparkan pelajaran tersebut kepada anak-anak melalui aplikasi google Classrom. Dengan sekali klik gambar ataupun video yang akan disampaikan kepada para siswa dengan mudah terkirim dalam hitungan yang relative cepat. Nah, siswa yang tergabung dalam Classroom bisa langsung mengecek diaplikasi masing-masing dan segara mengerjakan tugas yang diberikan oleh bapak /Ibu guru dikelas.

Pelaksanaan metode pembelajaran tentunya membutuhkan langkah-langkah awal dalam menyukseskan pembelajaran di suatu Lembaga Pendidikan. Pembelajaran yang baik tentunya diawali oleh langkah yang tepat oleh seorang guru melalui beberapa metode yang sesuai. ${ }^{3}$ Langkah-langkah tersebut perlu dilakukan oleh para guru baik pengampu pelajaran tematik maupun guru PAI. Butuh metode-metode yang relevan dengan perkembangan yang ada, sebagai salah satu pendukung pembelajaran yang harus dilakukan oleh guru-guru PAI adalah dengan menggunakan metode Classroom.

3 Wina Sanjaya, Strategi Pembelajaran, Kencana Prenadamedia Group, 2006, hal. 147 
JURNAL PIWULANG, Vol. 2 No. 2 Maret 2020, 129-143

P-ISSN : 2622-5638. E-ISSN : 2622-5654

Homepage: http://e-journal.staima-alhikam.ac.id/index.php/piwulang

Penggunaaan komputer sebagai media pembelajaran dalam Google Classroom secara umum mengikuti proses intruksional sebagai berikut:4

1. Merencanakan, mengatur, dan mengorganisasikan serta menjadwalkan pengajaran. Di aplikasi ini telah dirancang berbagai pembelajaran untuk mencapai suatu tujuan pembelajaran PAI. Google classroom juga berkaitan dengan pengelompokan dan penjadwalan pengajaran mata pelajaran agama.

2. Mengevaluasi siswa-siswi. Google Classroom dapat menjadi bahan evaluasi siswa. Sebagai contoh siswa mengikuti ujian melaui aplikasi google classroom, sebelum melaksanakan ujian, guru terlebih dahulu mengunggah soal di aplikasi ini.

3. Mengumpulkan informasi data siswa. Pada google classroom terdapat data siswa, yang memudahkan proses penilaian dan pengajaran. Informasi tersebut meliputi biodata lengkap siswa, nilai siswa, data keaktifan siswa pada aplikasi google classroom.

4. Melakukan analisis statistik mengenai data pembelajaran. Analisa statistik dalam google classroom bertujuan untuk pengumpulan data siswa. Adapun data yang dikumpulkan seperti, kreatifitas siswa dan keaktifan siswa pada aplikasi.

5. Catatan perkembangan proses belajar kelompok dan individu. Catatan perkembangan pembelajaran kelompok atau individu dalam google classroom sangat penting. sebagai bahan evaluasi siswa untuk melihat seberapa jauah siswa aktif apada aplikasi google classroom.

Bagi pemula tentunya langkah-langkah sebagaimana dijelaskan diatas terbilang rumit, dan itu semua bisa teratasi dengan baiak melalui pembiasaan yang terus-menerus, sehingga dari pembiasaan tersebut para siswa menjadi terbiasa dalam pengoprasian apalikasi tersebut. Menjadi tantangan tersendiri bagi seorang pendidik untuk melatih anak-anaknya agar senantisa berlatih lebih baik dalam mengerjakan tugas-tugas melalui aplikasi tersebut. Suka ataupun tidak kemajuan jaman yang diikuti oleh perkembangan teknologi akan memaksa peserta didik untuk menghikuti kemauan dari teknologi itu sendiri. Menurut Hamalik, guru harus memiliki pengetahuan dan pemahaman yang cukup tentang media pembelajaran yang meliputi: ${ }^{5}$

\footnotetext{
${ }^{4}$ Abd Rozak, Azkia Muharrom Albantaini, Desain Perkuliahan Bahasa Arab Melalui Google Classrom, Vol 5 No.1, Juni 2018, diakses tanggal 17 oktober 2019

${ }^{5}$ Azhar Arshad, Media Pembelajran, PT Rajagrafindo Persada, tahun 2019, hal 2
} 
a. Media sebagai alat komunikasi guna lebih mengefektifkan proses belajar mengajar

b. Fungsi media dalam rangka mencapai tujuan Pendidikan

c. Seluk-beluk proses belajar

d. Hubungan antara metode mengajar dan media Pendidikan

e. Nilai atau manfaat media Pendidikan dalam pengajaran

f. Pemilihan dan penggunaan media Pendidikan

g. Berbagai jenis alat dan Teknik media Pendidikan

h. Media Pendidikan dalam setiap mata pelajarn

i. Usaha inovasi dalam media Pendidikan

Melalui Google Clasroom dihrapkan pembelajaran PAI disekolah akan lebih lebih maksimal dan efektif sesuai dengan tuntutan zaman yang serba modern dan pembelajaran disekolah diharapkan bisa menghasilkan sesuatu yang direncankan diawal tahun ajaran sesuai kurikulum yang ada, yang pastinya visi dan misi yang telah dicangankan sekolah dan selalu menjadi semboyan mereka setiap hari bisa tercapai sesuai yang diharapakan. Strategi pembelajaran harus dapat mendorong aktivitas siswa. ${ }^{6}$

Penggunaan aplikasi tersebut adalah salah satu upaya yang dilakukan oleh seorang guru dalam pembelajaran PAI. Seperti diketahui secara umum disekolah-sekolah berbasis agama seperti di MI Islamiyah bidang studi PAI terdapat bermacam-macam mata pelajaran, seperti 1) Al-Qur'an hadits, 2) Fiqih, 3) Aqidah Akhlak, 4) Bahasa Arab 5) Sejarah Kebudayaan Islam (SKI) 6) Mata Pelajaran ASWAJA (ke-NU-an).

\section{3) Kelebihan \& Kekurangan Penggunaan Google Classroom dalam Pembelajaran PAI}

Pemanfaatan aplikasi dalam proses belajar mengajar sebagai mana disampaikan oleh Abd Rozak dkk dalam karya tulisnya tentunya memiliki kelebihan-kelebihan, antara lain: ${ }^{7}$

a. Proses pengaturan yang cepat

Dengan kecanggihan yang dimiliki, google classroom memungkinkan proses pengaturan ulang dengan cepat tanpa harus menginstal penunjang system pembelajaran lain. Dengan kemudahan yang ditawarkan pada aplikasi ini, guru dengan mudah mengaksesya dan memulai pembelajan dengan membagikan tugas-

\footnotetext{
${ }^{6}$ Wina Sanjaya, Strategi Pembelajaran, Kencana Prenadamedia Group, 2006, hal. 132

7 Abd Rozak, Azkia Muharrom Albantaini, Desain Perkuliahan Bahasa Arab Melalui Google

Classrom, Vol 5 No.1, Juni 2018, diakses tanggal 17 oktober 2019
} 
JURNAL PIWULANG, Vol. 2 No. 2 Maret 2020, 129-143

P-ISSN : 2622-5638. E-ISSN : 2622-5654

Homepage: http://e-journal.staima-alhikam.ac.id/index.php/piwulang

tugas kepada anak didik. Google Clasroom lebih sederhana dan mudah untuk digunakan, sehingga ideal bagi guru meskipun dengan tingkat pengalaman yang beragam dan minim.

b. Hemat ruang dan waktu

Aplikasi ini memudahkan bapak/ibu guru dalam memberikan tugas kepada para siswa. Pun sebaliknya, siswa bisa dengan mudah mengetahui tugas-tugas yang diberikan kepada mereka kapan dan dimanapun mereka berada selama jaringan internet sebagai pendukung aplikasi ini tersedia. Dalam penerapannya juga memudahkan guru selaku tutor dalam kelas tersebut menilai secara cepat dan memberikan pesan berkaitan dengan tugas yang diberikan.

c. Meningkatkan disiplin para siswa.

Maksudnya adalah dengan metode ini para siswa diharapkan bisa belajar lebih disiplin dengan mengikuti aturan yang diberikan oleh guru. Setiap tugas hanya bisa diterima/dilayani dengan menggunakan aplikasi tersebut. Sehingga para siswa tertib dengan aturan yang ada.

d. Meningkatkan kerjasama dan komunikasi kelas

Ketika menggunakan aplikasi ini, guru dapat berdiskusi dengan siswa dengan memulai dengan komunikasi sederhana, seperti salam dan sapa. Dengan cara ini bisa meningkatkan komunikasi dengan mereka meskipun ada jarak yang memisahkan kedua belah pihak (antara guru dan siswa) karena tidak bisa bertatap muka sebagaimana biasanya di dalam kelas. Akan tetapi, dengan komunikasi dengan baik lewat aplikasi ini komunikasi dan kerja sama tetap terjaga/solid.

e. Penyimpanan data terpusat

Dengan memaksimalkan kemudahan yang tersedia pada aplikasi ini, semua data dokumen dan tugas yang diberikan oleh guru tersimpan dengan baik pada tempat yang tersedia. Siswa bisa menyimpan tugas-tugas yang mereka terima dalam folder khusus dengan memberi nama yang mudah diingat mereka. Bahan ajar dan data nilai guru juga bisa disimpan dalam aplikasi ini. Guru dan siswa juga tidak perlu khawatir tentang data-data mereka karena telah tersimpan dengan rapi dalam google classroom.

f. Terjangkau, aman, dan nyaman

Terjangkau di sini maksudnya guru dan siswa dengan mudah memiliki aplikasi tersebut dengan tanpa memerlukan biaya yang mahal, hanya dengan bermodal data internet mereka bisa bisa membuat akun tersebut secara gratis tanpa dipungut biaya 
JURNAL PIWULANG, Vol. 2 No. 2 Maret 2020, 129-143

P-ISSN : 2622-5638. E-ISSN : 2622-5654

Homepage: http://e-journal.staima-alhikam.ac.id/index.php/piwulang

tambahan. Tingkat keamanan aplikasi ini ini tidak perlu diragukan lagi karena sudah diatur sedemikian rupa oleh Google selama kata kunci akun tidak diketahui oleh pihak manapun kecuali pemiliknya. Nyaman, semua siswa yang tergabung dalam classroom tersebut bisa berkomunikasi secara langsung kepada guru tanpa diketahui oleh teman-temannya yang mungkin tidak bisa diceritakan kepada teman yang setara usianya.

g. Tetap teratur

Aplikasi ini memudahkan pemiliknya menyimpan data secara rapi dan teratur dengan membuat folder tertentu yang sesuai dengan keinginan dan mudah diingat apabila dibutuhkan dikemudian hari.

Kelebihan yang yang ada dalam aplikasi Google classroom mungkin sangat bisa dirasakan oleh para guru dan murid dalam proses belajar mengajar di kelas. Akan tetapi secanggih apapun suatu produk yang dikembangkan dalam proses belajar dan mengajar di dalam kelas pasti ada kekurangan-kekurangan sebagai konsekuensi yang akan dihadapi oleh pemakai aplikasi tersebut, diantaranya adalah sebagai berikut: 8

a) Buruknya jaringan wi-fi di seolah.

Kebutuhan wi-fi disekolah mutlak diperlukan untuk menunjang proses belajar mengajar melalui aplikasi ini. Karena sistem kerjanya harus berbasis internet dimana lembaga harus menyiapkan sarana tersebut demi kelancaran pengunaan media google classroom.

b) Tidak ada sistem notification dari aplikasi Google Classroom

Tidak semua aplikasi sosial media yang diunduh ditelepon seluler memberikan notifikasi peringatan ketika melakukan aktivitas pada akun yang kita miliki. Jadi, pengguna akun/siswa harus sering memeriksa apabila ada tuga-tugas yang diberikan guru. Sehingga mereka tidak ketinggalan informasi ataupun tugas-tugas yang diberikan melaui google classroom.

c) Hilang satu hilang seribu.

Google classroom adalah aplikasi yang selalu tersingkronisasi dengan google drive sebagai tempat untuk menyimpan data-data penting. Jika aplikasi untuk membuka tugas-tugas tersebut hilang, maka semua data yang tersimpan dalam google drive pun akan

\footnotetext{
${ }^{8}$ Abd Rozak, Azkia Muharrom Albantaini, Desain Perkuliahan Bahasa Arab Melalui Google Classrom, Vol 5 No.1, Juni 2018, diakses tanggal 17 Oktober 2019
} 
JURNAL PIWULANG, Vol. 2 No. 2 Maret 2020, 129-143

P-ISSN : 2622-5638. E-ISSN : 2622-5654

Homepage: http://e-journal.staima-alhikam.ac.id/index.php/piwulang

hilang semua. Oleh karena itu, setiap pengguna harus berhati-hati dalam menggunakannya. Biasakan untuk log out aplikasi ini jika tugas-tugas yang dikerjakan telah selesai untuk menghindari sesuatu yang tidak diinginkan, misalnya hilangnya dokumendokumen yang telah tertata dengan rapi dalam aplikasi tersebut.

\section{4) Urgensi Metode Pembelajaran PAI Melalui Google Classrom}

Pemakaian sebuah media pembelajaran dengan menggunakan aplikasi tersebut bisa di gunakan oleh guru pengampu mata pelajaran umum dan mata pelajaran agama (PAI). Di pendidikan dasar penyampaian materi pembelajaran haruslah mulai membiasakan dengan mengikuti perkembangan jaman. Guru maupun lembaga haruslah cerdas dengan mengikuti perkembangan yang ada dengan mencari informasi-informasi yang terkini berkaitan dengan peningkatan kualitas dan pelayanan kepada masyarakat (baca: wali murid), agar penyampaian ilmu kepada siswa bisa tersampaikan dengan baik dan cepat.

Penyampaian pembelajaran dengan google classroom merupakan pembelajaran dengan memanfaatkan teknologi internet untuk meningkatkan lingkungan belajar dengan konten yang kaya dengan cakupan yang luas. Pembelajaran tersebut merupakan pemanfaatan media pembelajaran menggunakan internet, untuk mengirimkan serangkaian solusi yang dapat meningkatkan pengetahuan dan keterampilan. Setiap metode pembelajaran harus mengandung rumusan pengorganisasian bahan pelajaran, strategi penyampaian, dan pengelolaan kegiatan dengan memperhatikan faktor tujuan belajar, hambatan belajar, karakteristik peserta didik, agar dapat diperoleh efektivitas, efisiensi, dan daya tarik pembelajaran .

Pentingnya implementasi dalam pembelajaran PAI dengan menggunakan google classroom, maka akan diketahuai keefektifan pembelajaran berbasis google classroom, yaitu: ${ }^{9}$

a. Mengetahui pengaruh penerapan Google Classroom pada proses belajar mengajar di kelas maupun diluar kelas;

b. Mengidentifikasi keefektifan perancangan dan pembuatan materi pembelajaran pada Google Classroom;

\footnotetext{
${ }^{9}$ Sabran dan Edy Sabara, Keefektifan Google Classroom sebagai media pembelajaran, Fakultas Teknik Universitas Negeri Makassar, ISBN : 978-602-5554-71-1, diakses pada tanggal 26 Nov 2019
} 
JURNAL PIWULANG, Vol. 2 No. 2 Maret 2020, 129-143

P-ISSN : 2622-5638. E-ISSN : 2622-5654

Homepage: http://e-journal.staima-alhikam.ac.id/index.php/piwulang

c. Mengidentifikasi ke-efektifan evaluasi pelaksanaan pembelajaran dengan Google Classroom.

d. Mengetahui respon siswa didik terhadap pembelajaran menggunakan Google Classroom yang diterapkan pada proses belajar mengajar.

Pemakaian media pembelajaran dewasa ini diungkapkan oleh Fatah Syukur, sebagaimana dikutip oleh Ali Mufron haruslah memiliki fungsi: ${ }^{10}$

1. Membantu memudahkan belajar siswa dan memudahkan pengajaran bagi guru

2. Memberikan pengalaman lebih nyata

3. Menarik perhatian siswa lebih besar, sehingga siswa lebih antusias untuk mengikuti pelajaran.

4. Semua panca indera yang dimiliki masing-masing murid dapat diaktifkan.

5. Dapat membangkitkan dunia teori dengan realitanya.

Dengan mengaplikasikan pembelajaran melaui google classroom diharapkan bisa memudahkan proses pemindahan ilmu dari seorang guru kepada para siswa. Khususnya guru-guru pengampu pelajaran agama bisa mengirimkan materi yang akan disampaikan kepada para siswa dengan menggunakan kemudahan yang dimiliki oleh aplikasi tersebut. Sekali kirim akan dengan mudah diterima oleh siswa yang tergabung dalam kelas yang dibimbing oleh guru pengampu.

Guru mata pelajaran fiqih bisa menyampaikan materi-materi yang ingin disampaikan kepada anak didiknya, salah satu contohnya adalah materi tentang Makanan Halal dan Makanan Haram kepada siswa kelas 6 Madrasah Ibtidaiyah bisa membuat gambar-gambar agar para siswa bisa membayangkan apa saja yang termasuk dalam pembahasan materi terlebih dahulu sebelum mengirimkan kepada para siswanya melalui aplikasi tersebut. Cara itu dilakukan karena anakanak dengan tingkatan sekolah dasar / Madrasah Ibtidaiyah sangat menyukai gambar ataupu video-video tertentu untuk mengajak para siswa membayangkan ataupun melihat langsung dalam bentuk visualisasi yang nantinya bisa dibuktikan diluar sekolah secara langsung baik di lingkungan keluarga maupun tempat bermain Bersama teman-temannya.

${ }^{10}$ Ali Mufron, Ilmu Pendidikan Islam, Aura Pustaka, Yoyakarta, Tahun 2013, hlm. 112 
JURNAL PIWULANG, Vol. 2 No. 2 Maret 2020, 129-143

P-ISSN : 2622-5638. E-ISSN : 2622-5654

Homepage: http://e-journal.staima-alhikam.ac.id/index.php/piwulang

Waktu pulang sekolah dengan berjalan kaki menuju kampung tempat tinggalnya, tiba-tiba bertemu dengan seekor anjing yang melintas tidak jauh dari tempatnya berada. Apabila seorang siswa terebut bisa menangkap dengan baik pelajaran tentang jenis makanan Haram yang telah di berikan oleh gurunya disekolah melalui google classroom yang dia miliki, dan dia bisa membuktikan bahwa apa yang disampaikan disekolah bisa dibuktikan di lingkungan tempat tinggalnya

Pada prinsipnya proses pembelajaran yang dilakukan oleh guru PAI adalah pemberian contoh kepada anak didik mereka (Uswatun Hasanah) yang itu bisa bisa didapatkan dengan cara melihat langsung dari seorang guru pengampu Pendidikan Agama Islam (PAI). Pendidik pada hakikatnya adalah orang dewasa yang bertanggungjawab memberi pertolongan pada peserta didiknya dalam perkembangan jasmani dan rohaninya agar mencapai tingkat kedewasaannya, mampu berdiri sendiri, dan memenuhi tingkat kedewasaannya, mampu mandiri dalam memenuhi tugasnya sebagai hamba Allah dan khalifah Allah SWT dan mampu melaksanakan tugas sebagai makhluk sosial dan makhluk individu yang mandiri. ${ }^{11}$ Oleh karena itu, pendidik mempunyai kedudukan yang tinggi dalam islam. ${ }^{12}$

Boleh kita mengandalkan kecangggihan alat-alat yang ada saat ini untuk mempermudah pekerjaaan sehari-hari, akan tetapi jangan pernah mengesampingkan proses belajar mengajar yang telah berjalan sebelumnya demi menjaga kedekatan emosional antara seorang guru kepada muridnya. Lebih-lebih guru PAI yang lebih banyak mengandalkan pemberian contoh secara langsung kepada para siswa sebagai mana yang telah dicontohkan oleh para ulama kepada para santrinya, bahkan sejarah islam membuktikan proses belajar mengajar yang telah diterapkan Rosulullah kepada para sahabat-NYa. Itu berarti sebagai ummat-Nya kita patut mengikuti jalan dakwah mereka.

\section{KESIMPULAN}

Google classroom adalah aplikasi yang dirancang sebagai salah satu cara untuk mempermudah proses belajar mengajar, yang mana kegiatan tersebut mengharuskan interaksi antara guru dengan siswa yang dilakukan di luar kelas dengan sarana internet. Aplikasi ini bisa

\footnotetext{
11 Ali Mufron, Ilmu Pendidikan Islam, Aura Pustaka, Yogyakarta, Tahun 2013, hal 31

12 Sulistyorini, Meretas Pendidkan Berkualitas dalam Pendidikan Islam, Penerbit Teras:2012, hal. 18
} 
JURNAL PIWULANG, Vol. 2 No. 2 Maret 2020, 129-143

P-ISSN : 2622-5638. E-ISSN : 2622-5654

Homepage: http://e-journal.staima-alhikam.ac.id/index.php/piwulang

dimanfaatkan untuk berdiskusi, saling melempar pertanyaan serta berbagi tugas-tugas yang harus dikerjakan baik mandiri maupun kelompok.

Dalam mengaplikasikan pembelajaran melalui google classroom ini tentunya harus melalui langkah-langkah yang diperlukan dalam menjalankan proses pembelajaran di dalam kelas maupun diluar kelas. Penggunaaan komputer sebagai media pembelajaran dalam harus mengikuti aturan yang telah ditentukan dalam pengoperasian aplikasi ini. Antara lain merencanakan, mengatur dan menjadwal pengajaran; mengevaluasi siswa; mengumpulkan data mengenai siswa; menganalisis statistik data pembelajaran; Membuat catatan perkembangan pembelajaran kelompok atau perorangan. Bagi pemula dalam menerapkan langkah-langkah ini bukanlah pekerjaan yang mudah, akan tetapi dengan latihan secara intens penerapan pembelajaran melalui classroom bisa dijalankan dengan mudah.

\section{DAFTAR PUSTAKA}

Khoirul Anam, Faris. "Kata Pengantar Menteri Agama RI Lukman Hakim Saifudin”, Buku Fiqih Media Sosial, tahun 2019

Sanjaya, Wina. Strategi Pembelajaran, Kencana Prenadamedia Group, tahun 2006

Arshad, Azhar. Media Pembelajran, PT Rajagrafindo Persada, tahun 2019

Mufron, Ali. Ilmu Pendidikan Islam, Aura Pustaka, Yoyakarta, Tahun 2013

Sulistyorini. Meretas Pendidkan Berkualitas dalam Pendidikan Islam, Penerbit Teras, 2012

Rozak, Abdul dan Albantaini, Azkia Muharrom. Desain Perkuliahan Bahasa Arab Melalui Google Classrom, Vol 5 No.1, Juni 2018, diakses tanggal 17 oktober 2019

Sabran dan Edy Sabara. Keefektifan Google Classroom sebagai Media Pembelajaran, Fakultas Teknik Universitas Negeri Makassar, ISBN : 978-602-5554-71-1, diakses pada tanggal 26 Nov 2019 